\title{
Ailanthone induces autophagic and apoptotic cell death in human promyelocytic leukemia HL-60 cells
}

\author{
CHENG WEI $^{1}$, CHUANRONG CHEN $^{2}$, YUXIN CHENG $^{3}$, LIN ZHU $^{3}$, YU WANG $^{3}$, \\ $\mathrm{CAN} \mathrm{LUO}^{3}$, YANG HE${ }^{1}$, ZHIMING YANG $^{1}$ and ZHAONING JI ${ }^{1}$ \\ ${ }^{1}$ The Cancer Center, Yijishan Hospital of Wannan Medical College; ${ }^{2}$ Department of Oncology, \\ Wuhu No. 2 People's Hospital, Wuhu, Anhui 241001; ${ }^{3}$ Department of Oncology, \\ Wannan Medical College, Wuhu, Anhui 241003, P.R. China \\ Received January 16, 2018; Accepted July 3, 2018
}

DOI: $10.3892 / \mathrm{ol} .2018 .9101$

\begin{abstract}
Ailanthone, which is extracted from the traditional Chinese medicinal plant Ailanthus altissima, has been thoroughly demonstrated to have anti-tumor, anti-HIV, anti-inflammatory, anti-malarial, anti-allergic and anti-microbial activities. However, the anti-proliferative effects of ailanthone on HL-60 cells and potential mechanisms underlying those effects have not been reported. In the present study, we demonstrated the potent cytotoxicity of ailanthone against HL-60 cells. Annexin V-APC/7-ADD staining assay indicated that ailanthone increased the number of apoptotic cells in a dose-dependent manner. PI staining showed that ailanthone increased the percentage of G0/G1-phase cells in a dose-dependent manner. Acridine orange staining suggested that ailanthone induced the formation of acidic vesicular organelles in HL-60 cells and pretreatment with BaF-A1 could attenuate this process. Western blotting showed that ailanthone up-regulated the protein expression levels of beclin-1 and LC3-II and down-regulated those of LC3-I and p62 in a dose-dependent manner. Use of BaF-A1 showed that the anti-proliferative effects of ailanthone on HL-60 cells may be partly attributable to the induction of autophagy-mediated apoptosis by MTT assay and annexin V-APC/7-ADD staining assay.
\end{abstract}

\section{Introduction}

Leukemia makes up about 1/3 of the case of cancer in people younger than 15 years old and is not uncommon in adults (1). Despite significant advances in the chemotherapeutic management of leukemia, post-remission relapse occur frequently in

Correspondence to: Professor Zhaoning Ji, The Cancer Center, Yijishan Hospital of Wannan Medical College, 2 Zheshan West Road, Wuhu, Anhui 241001, P.R. China

E-mail: jzn2016111@163.com

Key words: ailanthone, apoptosis, autophagy, HL-60 cells, beclin-1, LC3I/II, p62 most patients (2). In this way, it is imperative to find more efficient low-toxicity agents to use in chemo-preventive therapies for leukemia.

Ailanthone, which is extracted from traditional Chinese medicinal plant Ailanthus altissima (3), has been well-demonstrated to have anti-tumor, anti-HIV, anti-inflammatory, anti-malarial, anti-allergic, and anti-microbial activities $(4,5)$. The growth-inhibitory effect of ailanthone on varieties of tumor cells (He La, Jurkat, Hep G2, Hep3B, R-Hep G2, MCF-7, MDA-MB-231, Huh7 and A549) in vitro has been reported (6-9). However, the cytotoxicity of ailanthone on human HL-60 leukemia cells and its underlying molecular mechanism are poorly understood.

Apoptosis, type I programmed cell death, is a series of physiological changes that are mediated by genes and proteins, and the cells depend on this mechanism to activate their own destruction. If pathological interference take place during the process of apoptosis, malignant tumors may form (10-12). Autophagy, type II programmed cell death, is a conserved decomposition process that allows the degradation and recycling of cytoplasm, aggregated proteins, and excess or defective organelles (13). Autophagy is mainly a response to the stress of irradiation (14), chemotherapeutic drugs (15), or starvation (16). Despite its contribution to cell survival, previous studies have demonstrated that several anti-tumor agents induce cell death with autophagic features in various cancer cells (17-19).

In the present study, we sought to investigate the cytotoxicity of ailanthone in human HL-60 leukemia cells in vitro and to elucidate the mechanisms that may underlie its actions. We are searching for a new natural anti-tumor drug that is efficient and has minimal toxicity.

\section{Materials and methods}

Materials. The pure ailanthone used in this study was extracted from Ailanthus altissima. The ailanthone sample (purity $>98 \%$ ) was provided by the Institute of Traditional Chinese Medicine and Natural Products, Jinan University (Guangzhou, China). Dimethyl sulfoxide (DMSO) was purchased from Shanghai Joey Chemical Reagent Co., Ltd., (Shanghai, China). 3-(4,5-dimethylthiazol-2-yl)-2,5-di- 
phenyl-tetrazoliumbromide (MTT) was purchased from Amresco, LLC, (Solon, OH, USA). Propidium iodide (PI) and acridine orange (AO) was purchased from Nanjing Key Gen Biotech Co., Ltd., (Nanjing, China) RPMI-1640 medium was purchased from Gibco; Thermo Fisher Scientific, Inc., (Waltham, MA, USA). Fetal bovine serum (FBS), penicillin/streptomycin solution (PS), and antibodies for LC3I/II, beclin-1, p62, GAPDH were obtained from Nanjing KeyGen Biotech Co., Ltd. Autophagy inhibitor Bafilomycin-A1 (BaF-A1) was purchased from Boster Biological Technology Co., Ltd., (Wuhan, China).

Cell line and culture. Human promyelocytic leukemia HL-60 cells were obtained from Nanjing Key Gen Biotech Co., Ltd. HL-60 cells were cultured in RPMI-1640 medium with $10 \%$ FBS and $1 \%$ PS solution in a humidifying thermostat with $5 \%$ $\mathrm{CO}_{2}$ at $37^{\circ} \mathrm{C}$. Stock solutions of ailanthone were prepared in DMSO and stored at $-20^{\circ} \mathrm{C}$ and diluted to the required concentration with RPMI-1640 complete medium.

MTT assay of cell viability. The cytotoxicity of ailanthone in human HL-60 cells was assessed by using the MTT assays. Exponentially growing HL-60 cells $\left(5 \times 10^{4}\right.$ cells/well) were seeded and cultured in 96-well plates for $24 \mathrm{~h}$ and then treated with various concentrations of ailanthone $(1.25,2.5,5,10$, and $20 \mu \mathrm{M}$ ) or $0.1 \%$ DMSO (control group) for 24,48 and $72 \mathrm{~h}$ at $37^{\circ} \mathrm{C}$. $20 \mu \mathrm{MTT}(5 \mathrm{mg} / \mathrm{ml})$ was added to each well of the plate and then cultured for $4 \mathrm{~h}$ at $37^{\circ} \mathrm{C}$. Subsequently, cells were washed in PBS followed by the addition of $150 \mu \mathrm{l}$ DMSO. Micro-plate spectrophotometer (RT-6000; Rayto Life and Analytical Sciences Co., Ltd., Shenzhen, China) was used to measure the optical densities at $490 \mathrm{~nm}$ spectral wavelength.

Flow cytometric analysis of cell apoptosis. HL-60 cells $\left(5 \times 10^{5}\right.$ cells/well) were seeded into 6 -well plates and cultured for $24 \mathrm{~h}$ at $37^{\circ} \mathrm{C}$, and were then treated with various concentrations of ailanthone $(5,10$, and $20 \mu \mathrm{M}$ ) or $0.1 \%$ DMSO (control group) for $48 \mathrm{~h}$ at $37^{\circ} \mathrm{C}$, respectively. Cells were washed twice in cold PBS, and then the cell pellets were mixed with annexin V APC/7-ADD (Nanjing Key Gen Biotech Co., Ltd.) for 15 min at $37^{\circ} \mathrm{C}$ in the dark. Cell apoptosis was were evaluated using a FACSCalibur Flow Cytometer (BD Biosciences, Franklin Lakes, NJ, USA) and the rate of cell death was analyzed using a FACSCalibur internal software system (BD Biosciences).

Flow cytometric analysis of cell cycle. HL-60 cells $\left(5 \times 10^{5}\right.$ cells/well) were seeded into 6-well plates and cultured for $24 \mathrm{~h}$ at $37^{\circ} \mathrm{C}$, and then treated with various concentrations of ailanthone $(5,10$, and $20 \mu \mathrm{M}$ ) or $0.1 \%$ DMSO (control group) for $48 \mathrm{~h}$ at $37^{\circ} \mathrm{C}$, respectively. Cells were fixed and rendered permeable with $70 \%$ cold ethanol at $4^{\circ} \mathrm{C}$. After this interval, cells were treated with $1 \%$ RNase and stained with PI solution for $30 \mathrm{~min}$ at $4^{\circ} \mathrm{C}$. Cell cycle phase distribution of cells was established by FACSCalibur flow cytometer (BD Biosciences) using the cell cycle analysis software (FlowJo LLC, Ashland, OR, USA).

Detection of autophagy by AO staining. AO staining was used to detect the presence of acidic vesicular organelles (AVOs) after ailanthone treatment. HL- 60 cells $\left(5 \times 10^{5}\right.$ cells/well $)$ were treated with ailanthone at concentrations of $10 \mu \mathrm{M}$ or $0.1 \%$ DMSO (control group) for $48 \mathrm{~h}$ at $37^{\circ} \mathrm{C}$, and then cells were washed twice in cold PBS and fixed with $4 \%$ formaldehyde for $10 \mathrm{~min}$. After the treatment, cells were stained with $5 \mu \mathrm{g} / \mathrm{ml}$ AO solution for $15 \mathrm{~min}$ at $37^{\circ} \mathrm{C}$ in the dark and observed using an inverted fluorescence microscope (OlympusIX5; Olympus Corporation, Tokyo, Japan).

Western blotting. HL-60 cells $\left(5 \times 10^{6}\right.$ cells/well) were washed twice in cold PBS and suspended in radio immune-precipitation assay lysis buffer (Nanjing Key Gen Biotech Co., Ltd.) on ice for $30 \mathrm{~min}$, then treated with various concentrations of ailanthone $(5,10$, and $20 \mu \mathrm{M})$ or $0.1 \%$ DMSO (control group) for $48 \mathrm{~h}$ at $37^{\circ} \mathrm{C}$, respectively. The lysates were then cleared by centrifugation at $14,000 \mathrm{x}$ for $15 \mathrm{~min}$ at $4^{\circ} \mathrm{C}$. Subsequently, a bicinchoninic acid protein assay kit (Nanjing Key Gen Biotech Co., Ltd.) was used to measure the total protein concentration of each sample. The Protein samples $(30 \mu \mathrm{g})$ were separated by $15 \%$ SDS-PAGE in each group and then transferred onto polyvinylidene difluoride membranes (Pall Life Sciences, Port Washington, NY, USA). Membranes were stuck with 5\% (w/v) non-fat dry milk dissolved in TBS containing $0.05 \%$ Tween-20 (TBST) at room temperature for $1 \mathrm{~h}$, and then washed three times with TBST. Subsequently, membranes were incubated with primary antibodies against beclin-1 (1:200), p62 (1:200), LC3I/II (1:200), and GAPDH (1:400) for $12 \mathrm{~h}$ at $4^{\circ} \mathrm{C}$. The members were washed three times with TBST, and then incubated with HRP-conjugated goat anti-rabbit $(1: 2,000)$ IgG (Nanjing Key Gen Biotech Co., Ltd.) secondary antibodies at room temperature for $1 \mathrm{~h}$. The immune-reactive bands were visualized with enhanced chemiluminescent substrates (Thermo Fisher Scientific, Inc.) using an X-ray film processor (Kodak, Rochester, NY, USA). GAPDH served as a loading control. The experiment was independently repeated three times, and Quantity One software (v.4.6.2; Bio-Rad Laboratories, Inc., Hercules, CA, USA) was used to analyze the densitometry of each band.

Statistical analysis. Data are here expressed as means \pm SD. With SPSS software for windows v.17.0 (SPSS, Inc., Chicago, IL, USA), one way ANOVA followed by Newman-Keuls multiple comparison test was used for analysis of variance and the student's t-test was used for pair-wise comparison. $\mathrm{P}<0.05$ was considered to indicate a statistically significant difference.

\section{Results}

Ailanthone inhibits cell proliferation in HL-60 cells. Ailanthone share its chemical structure with the triterpenoids. Triterpenoids have many physiological activities, including anti-tumor activities (Fig. 1A). The MTT assay was used to assess the cytotoxicity of ailanthone in HL-60 cells. Treatment with ailanthone reduced the viability of HL-60 cells in a doseand time-dependent manner (Fig. 1B), with half maximal inhibitory concentration $\left(\mathrm{IC}_{50}\right)$ values of $12.18,8.497$, and $5.986 \mu \mathrm{M}$ after 24,48 , and $72 \mathrm{~h}$ of treatment, respectively.

Ailanthone induces apoptosis and cell cycle arrest in HL-60 cells. An annexin V-APC/7-ADD staining assay was used to confirm that ailanthone induced apoptosis in HL-60 
A

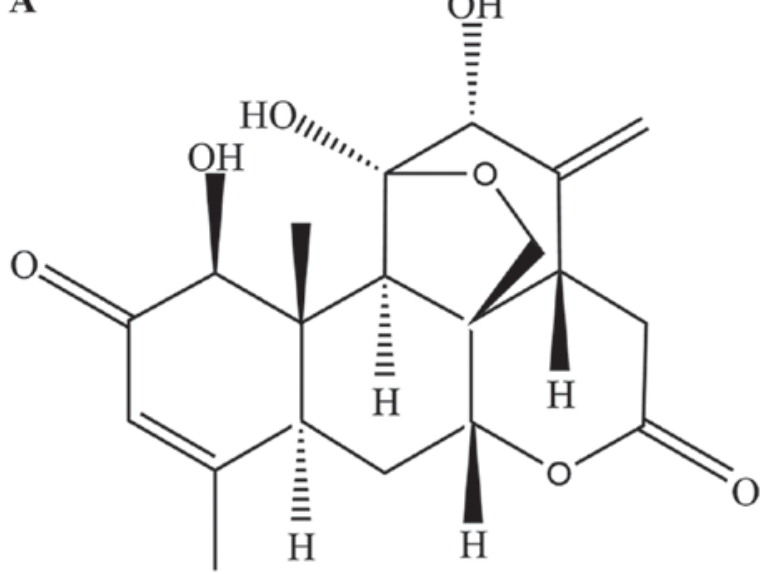

B

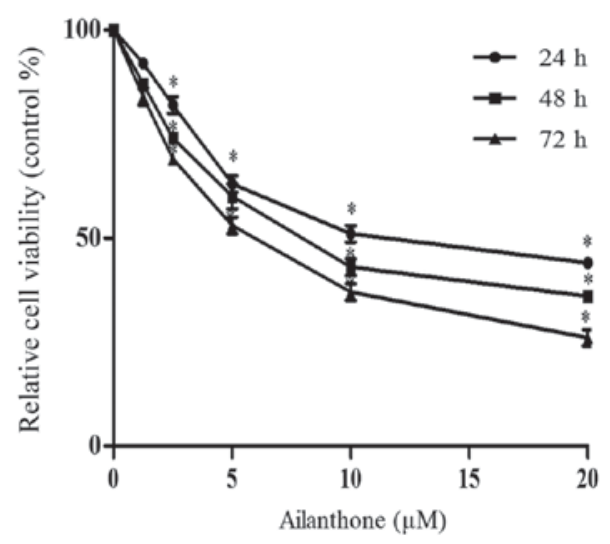

Figure 1. (A) Structure of ailanthone. (B) Ailanthone inhibited growth of HL-60 cells in a time- and dose-dependent manner. ${ }^{*} \mathrm{P}<0.05$ vs. $1.25 \mu \mathrm{M}$ groups.

cells. In the right quadrants of flow cytometry graphs, ailanthone significantly increased the number of apoptotic cells (Fig. 2A). After treatment with 5, 10, and $20 \mu \mathrm{M}$ ailanthone for $48 \mathrm{~h}$ at $37^{\circ} \mathrm{C}$, the rate of apoptosis among the cells was increased significantly from 42.02 to $59.68 \%$ and the percentage of apoptotic cells was $42.02 \pm 0.54,52.05 \pm 2.27$ and $59.69 \pm 0.25 \%$, which was significantly higher than in the control group $(3.92 \pm 0.14 \%$; $\mathrm{P}<0.05$; Fig. $2 \mathrm{~B})$. In order to determine whether the anti-proliferative effect of ailanthone on HL-60 cells was attributable to cell cycle arrest, we measured DNA content as an indicator of the cell cycle phase ratio by flow cytometry with PI staining (Fig. 3A). The percentage of G0/G1 cells increased significantly in a dose-dependent manner and cells in G0/G1 phase was $53.54 \pm 0.88,58.42 \pm 0.31$, and $65.57 \pm 3.16 \%$ in the 5,10 , and $20 \mu \mathrm{M}$ groups, respectively. Ailanthone treatment induced significant G0/G1-phase accumulation not observed in the control group (47.5 $\pm 2.54 \%$; $\mathrm{P}<0.05$; Fig. $3 \mathrm{~B})$.

Ailanthone induces autophagy in HL-60 cells. AO staining was used to observe the formation of acidic vesicular organelles, the main characteristics of autophagy (Fig. 4). Ailanthone induced noticeable formation of AVOs, which displayed red fluorescence in the lysosomal compartments of HL-60 cells (Fig. 4B). Control cells treated with 1\% DMSO displayed green fluorescence in the cytosolic and nuclear compartments, indicating the lack of AVOs (Fig. 4A). Those results showed that AVOs to be present in ailanthone-treated HL-60 cells, which suggest that ailanthone may induce autophagy in HL-60 cells. In addition, pretreatment with BaF-A1 displayed sporadic red fluorescence in the cells suggests that ailanthone-induced formation of AVOs in HL-60 cells were attenuated (Fig. 4C). Pretreatment with BaF-A1 without ailanthone also did not indicate the formation of AVOs (Fig. 4D). To investigate the effect of ailanthone on the protein expression levels in HL-60 cells that were associated with autophagy, we performed Western blot analysis to measure the levels of beclin-1, p62, and LC3-I/II (Fig. 5A). Treatment with ailanthone markedly increased beclin-1 levels but decreased and p62 levels (Fig. 5B). The ratio of LC3-I/II showed that treatment with ailanthone markedly increased LC3-II levels but decreased and LC3-I levels (Fig. 5C).
Autophagy is associated with ailanthone-mediated apoptosis of HL-60 cells. To investigate the role of autophagy in ailanthone-induced apoptosis, autophagy inhibitor BaF-A1 (1 or $2 \mathrm{nM}$ ) was used. Treatment with ailanthone significantly suppressed the viability of HL-60 cells, and the suppression was significantly attenuated by BaF-A1 (Fig. 6A). The rate of apoptotic in HL-60 cells was conspicuously reduced by BaF-A1 pretreatment (Fig. 6B and C). After treatment with 0 and $10 \mu \mathrm{M}$ ailanthone for $48 \mathrm{~h}$ at $37^{\circ} \mathrm{C}$, the rate of apoptosis among the cells pretreated with $2 \mathrm{nM} \mathrm{BaF-A1}$ was increased from $5.77 \pm 0.25$ to $26.93 \pm 1.74 \%$, which were significantly lower than in the group without pretreated with BaF-A1 (from 3.92 \pm 0.14 to $\left.52.05 \pm 2.27 \% ; \mathrm{P}<0.05^{\prime}\right)$. Those results suggested that the anti-proliferative effects of ailanthone on HL-60 cells may be partially due to the induction of autophagy-mediate apoptosis.

\section{Discussion}

Ailanthone, which is extracted from the traditional Chinese medicinal plant Ailanthus altissima (3), has been thoroughly demonstrated to have anticancer activity in previous studies (4-9). However, the anti-proliferative effects of ailanthone on HL-60 cells and mechanisms that may underlie these effects have been poorly understood. The present study is the first to demonstrate the potent-cytotoxicity of ailanthone against HL-60 cells. The mechanisms that underlie these effects may involve induction of autophagic cell death in HL-60 cells.

In the present study, we found that the rate of apoptosis in ailanthone-treated HL-60 cells to increase in a dose-dependent manner and this effect may be associated with an increase in the number of cells arrested at the G0/G1 phase. The cell cycle is the overall process of the cell from the beginning of a division to the end of the next division that allows the cell to proliferate, and is divided into four consecutive phases, known as G0/G1, S, and G2/M phases (20). Although G0 is often referred to as the quiescent phase, G0-phase cells are still quite with respect to cellular growth and are strictly regulated to determine when the cell will enter other stages of the cell cycle (21). The mitogenic signaling mediated by the RAS/RAF/MAPK pathway promotes this shift, whose endpoint is the stimulation of D-type cyclin production (22). 

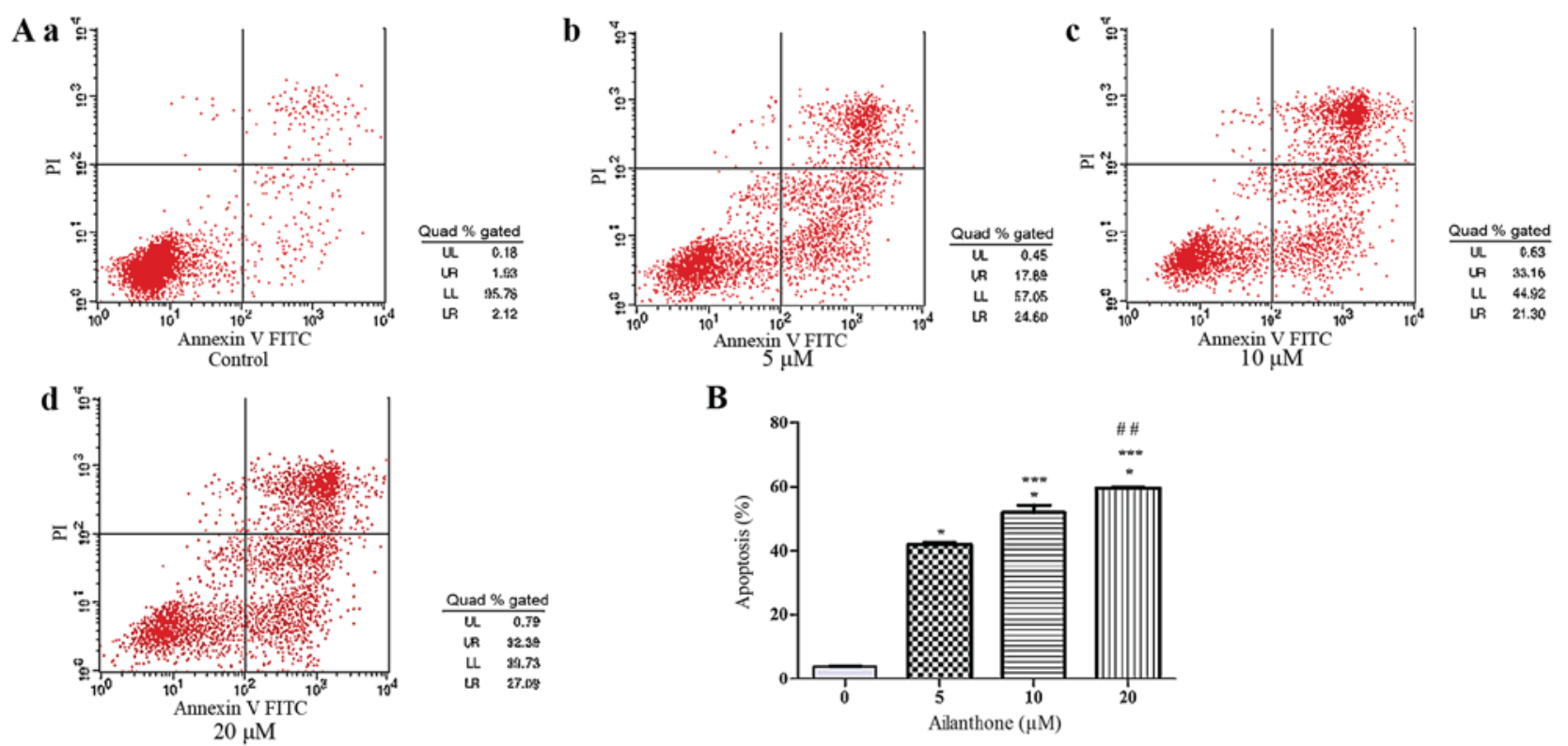

Figure 2. Ailanthone induced apoptosis in HL-60 cells. (A) Ailanthone induced apoptosis in HL-60 cells, which were stained by annexin V-APC/7-AAD fluid and assessed using flow cytometry analysis. (a) Control cells; Cells treated with (b) 5, (c) 10 , and (d) $20 \mu \mathrm{M}$ ailanthone for $48 \mathrm{~h}$ at $37^{\circ} \mathrm{C}$, respectively. Lower left (LL) quadrants: Viable cells. Lower right (LR) quadrants: Early apoptotic cells. Upper right (UR) quadrants: Late apoptotic cells. Upper left (UL) quadrants: Nonviable cells. (B) The data showed that ailanthone increased the percentage of apoptotic cells in a dose-dependent manner, ANOVA using Newman-Keuls multiple comparison test. ${ }^{*} \mathrm{P}<0.05$ vs. control, ${ }^{* * *} \mathrm{P}<0.05$ vs. $5 \mu \mathrm{M}$ groups, ${ }^{\# \#} \mathrm{P}<0.05$ vs. $10 \mu \mathrm{M}$ groups.

Our study suggested that ailanthone induces cell cycle arrest of HL-60 cells at the G0/G1 phase. In addition, a previous study found that ailanthone significantly induced cell cycle arrest at the G1/S phase in Huh-7 hepatocellular carcinoma cells (9). In eukaryotic cells, the process of $\mathrm{G} 2 / \mathrm{M}$ cell cycle is regulated by protein B (cyclinB)-p34cdc2, G2/M phase arrest takes place mainly in a p53-dependent manner. Watson et al (23), investigated a p53 wild-type MCF-7 cell line and p53 mutated MDA-MB-231 cell line. They found that the cell cycle of p53 wild-type MCF-7 cell line was arrested at the $\mathrm{G} 1$ and $\mathrm{G} 2$ phases under ionizing radiation, while p53 mutated MDA-MB-231 cells were arrested at the G2/M phase. Drug-induced cell cycle modulation not only varies between the same cell line treated with different drugs, but also in different cells after treatment with the same drug. Lavhale et al (24), found ailanthus excelsa chloroform extract-1 extracted from Ailanthus excels could induce S/G2-M cell cycle arrest in MDA-MB-231, MCF-7, and PC 3 cells and a G1 arrest in B16F10 cells. Treatment with AECHL-1 results in a significant decrease in the levels of c-Myc, CDK-4, and cyclin D1 in B16F10 cells, while the expression level of p21 was increased. p21 forms a complex with CDK2/CDK4/CDK6 and inhibits the CDK-cyclin kinase activity phase and arrests cells in the G1 phase (24). Therefore, we believe that the induction of cell cycle arrest at different phase by compounds extracted from ailanthus may be associated with a variety of factors, such as mutation of p53 gene and expression level of p21 in tumor cells and so on. In conclusion, these results demonstrated that the anti-proliferative effects of ailanthone on HL-60 cells were partially due to the induction of apoptosis and G0/G1 phase cell cycle arrest.

A previous study showed that some anti-cancer chemotherapy drugs can induce autophagic apoptosis in malignant tumor cells, thus inhibiting the proliferation of tumor cells $(25,26)$. In autophagy, targeted cytoplasm constituents are isolated from other parts of the cell, which forms a double membrane called autophagosome. Then, the autophagosome enters the lysosome through the cytoplasm, and the two organelles fuse. In the lysosome, the contents of the autophagosome are degraded by acidic lysosome hydrolase $(27,28)$. Our experiment indicated the presence of acidic vesicular organelles in HL-60 cells after treatment with ailanthone by AO staining, which suggested that ailanthone may induce HL-60 cells autophagy. Bafilomycin-A1 is a V-type ATPase inhibitor, which can prevent acidification and alters the membrane potential of some specific layers. Treatment with Baf-A1 will eventually lead to block in fusion of autophagosomes with lysosomes, thus preventing the maturity of autophagy $(29,30)$. There are several autophagy inhibitory reagents different from Baf-A1, such as E64d/pepstatin-A or chloroquine. E-64d is a membrane-permeable cysteine protease inhibitor, which can block the activity of a subset of lysosomal hydrolases. Pepstatin-A is an aspartyl protease inhibitor to inhibit lysosomal protein degradation. E-64d should be used in combination with pepstatin-A to inhibit lysosomal protein degradation (31). Chloroquine is lysosomal compounds, and elevate/neutralize the lysosomal/vacuolar $\mathrm{pH}$. Chloroquine improve the lysosomal $\mathrm{pH}$ value and the ultimately inhibition of autophagosomes and lysosome fusion, thereby preventing autophagosome maturation of autophagosomes into autoly-sosomes (32). Using E64d/pepstatin-A or chloroquine may better interpret the autophagy flux. However, our experiment refers whether or not autophagy is activated. Our currently study using Baf-A1 could clear to see the formations of autophagic vacuoles were suppressed under microscope.

We then investigated ailanthone-induced autophagy in HL-60 cells. The autophagy levels of the cells were found to be very low in a physiological environment; the major function 

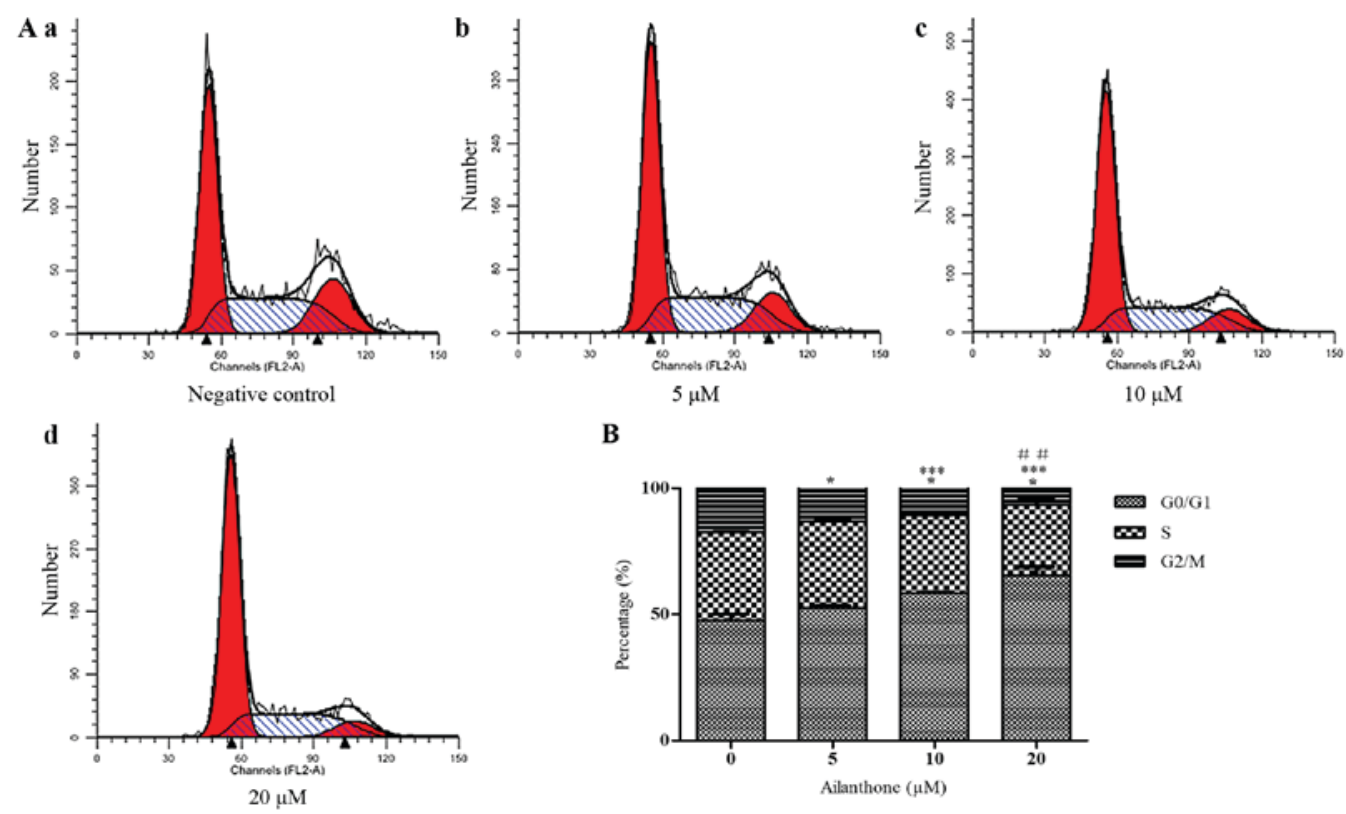

Figure 3. Ailanthone induced G0/G1 arrest in HL-60 cells. (A) Ailanthone induced G0/G1 arrest of HL-60 cells. Ailanthone induced cycle arrest in HL-60 cells, which were stained by PI fluid, and cell cycle distribution was analyzed by flow cytometry. (a) Control cells; Cells treated with (b) 5 , (c) 10 , and (d) $20 \mu \mathrm{M}$ ailanthone for $48 \mathrm{~h}$ at $37^{\circ} \mathrm{C}$, respectively. (B) The data showed that ailanthone increased the percentage of G0/G1-phase cells in a dose-dependent manner, ANOVA using Newman-Keuls multiple comparison test. ${ }^{*} \mathrm{P}<0.05$ vs. control, ${ }^{* * * *} \mathrm{P}<0.05$ vs. $5 \mu \mathrm{M}$ groups. ${ }^{\# \#} \mathrm{P}<0.05$ vs. the $10 \mu \mathrm{M}$ groups. PI, propidium iodide.

A

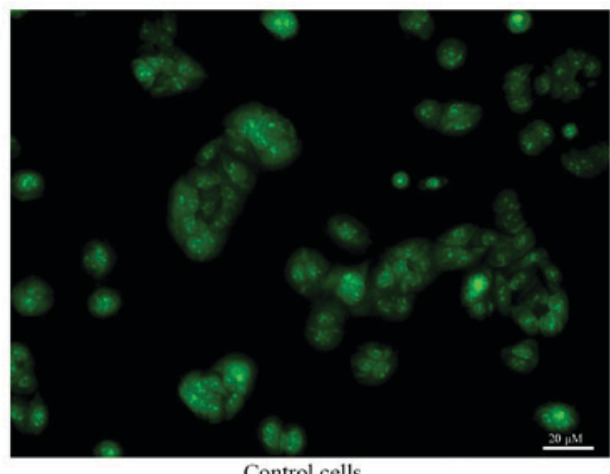

Control cells

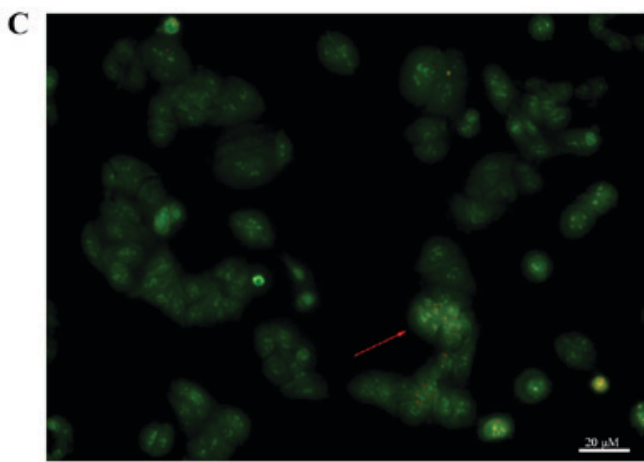

Ailanthone $(10 \mu \mathrm{M})+\mathrm{BaF}-\mathrm{Al}(2 \mathrm{nM})$
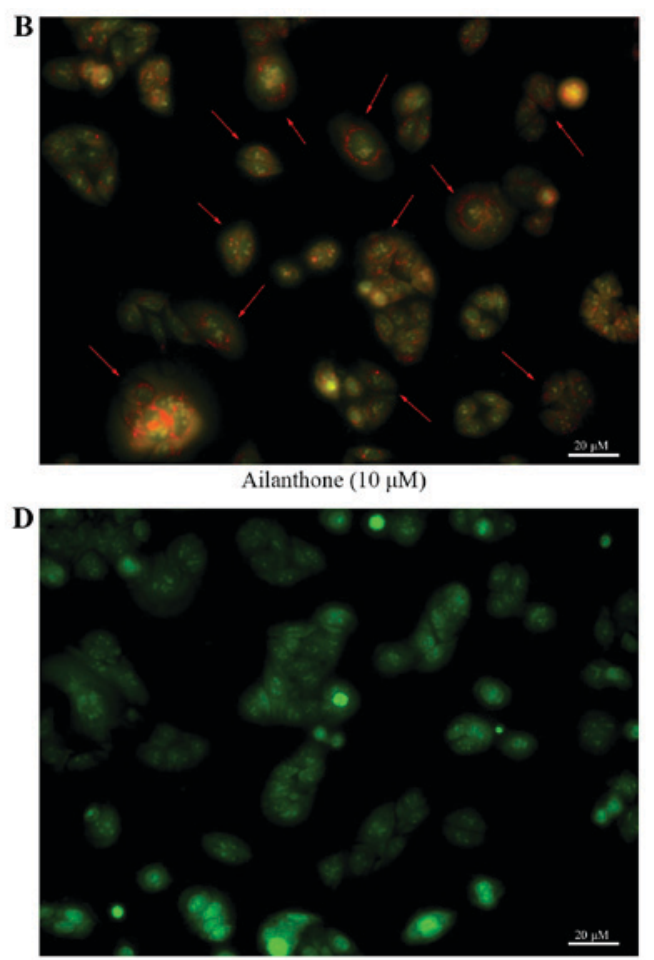

$\mathrm{BaF}-\mathrm{Al}(2 \mathrm{nM})$

Figure 4. Inverted fluorescence microscope detection of AVOs in HL-60 cells. (A) Control cells. (B) Cells treated with ailanthone (10 $\mu \mathrm{M})$ for $48 \mathrm{~h}$ at $37^{\circ} \mathrm{C}$. Red arrows indicate characteristic autophagy. (C) Cells were pretreated with BaF-A1 ( $2 \mathrm{nM})$ for 30 min, followed by treatment with ailanthone $(10 \mu \mathrm{M})$ for an additional $48 \mathrm{~h}$ at $37^{\circ} \mathrm{C}$. The red arrow indicates that autophagy is suppressed. (D) Cells were treated with BaF-A1 ( $\left.2 \mathrm{nM}\right)$ for $48 \mathrm{~h}$ at $37^{\circ} \mathrm{C}$ without ailanthone. These images suggest that ailanthone may induce HL-60 cell autophagy and pretreatment with BaF-A1 could attenuate this process. Scale bar, $20 \mu \mathrm{m}$. AVOs, acidic vesicular organelles.

of autophagy is degradation and recycling of senescent organelles and longevity proteins, which allow the cells to live longer (14-16). The role of autophagy in cells is paradoxical and when cells are faced with physiological or pathological stresses, the autophagy levels can increase significantly, which can lead to cell death $(33,34)$. Autophagy is associated with molecular regulation of autophagy associated protein, such as LC3, beclin-1, and p62. LC3 is an important protein 

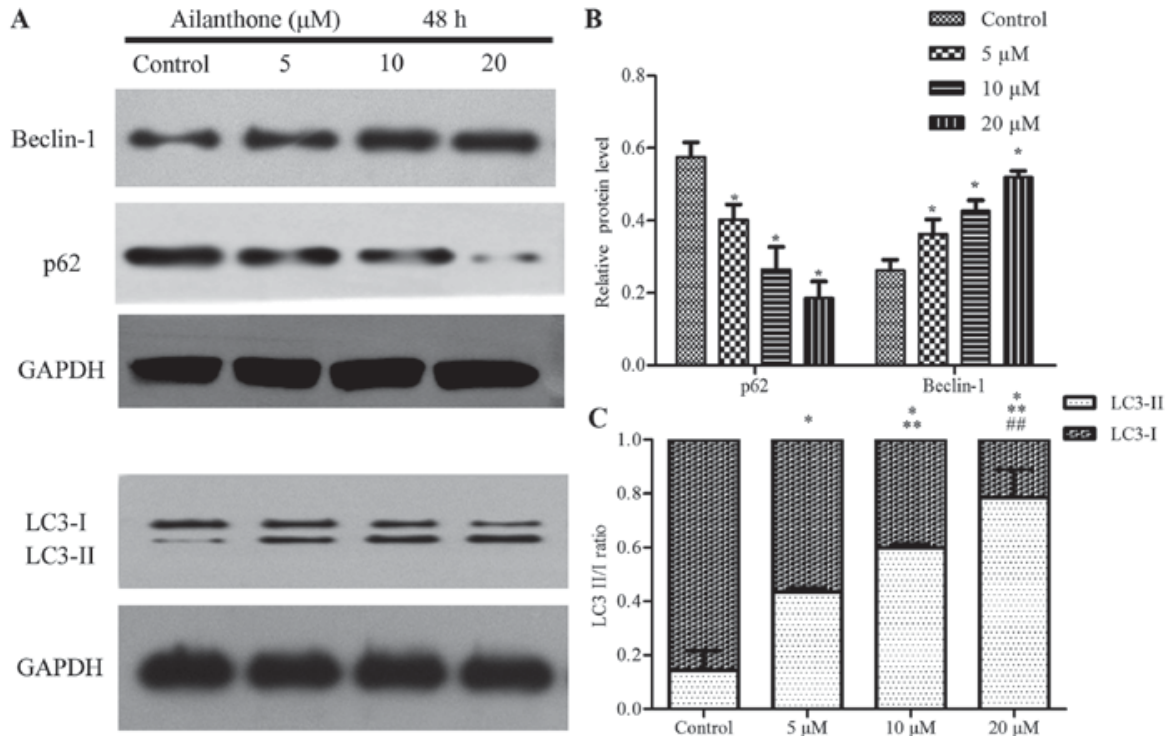

Figure 5. Protein expression levels in HL-60 cells. (A) Effects of ailanthone on the protein expression levels of beclin-1, p62, and LC3I/II in HL-60 cells were determined by western blotting after treatment with 5, 10, and $20 \mu \mathrm{M}$ ailanthone for $48 \mathrm{~h}$ at $37^{\circ} \mathrm{C}$. (B) The data showed the protein expression levels of beclin-1 to be up-regulated and down-regulated of p62 in a dose-dependent manner. (C) The results showed the protein expression levels of LC3-I to be down-regulated and LC3-II up-regulated in a dose-dependent manner, ANOVA using Newman-Keuls multiple comparison test. "P<0.05 vs. control. ${ }^{* *} \mathrm{P}<0.05$ vs. $5 \mu \mathrm{M}$ groups. ${ }^{\# \prime} \mathrm{P}<0.05$ vs. $10 \mu \mathrm{M}$ groups.

A
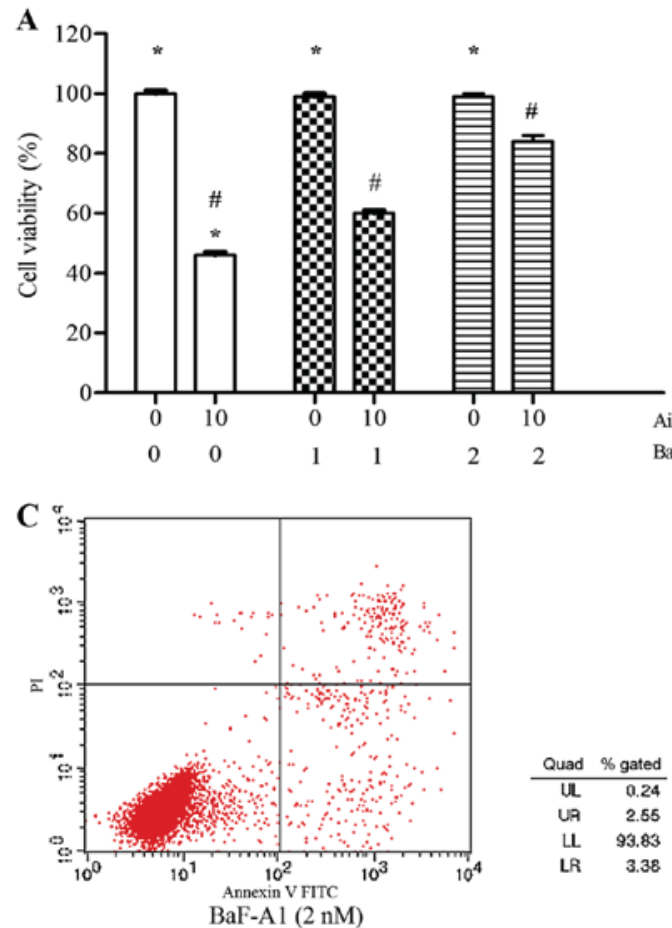

B

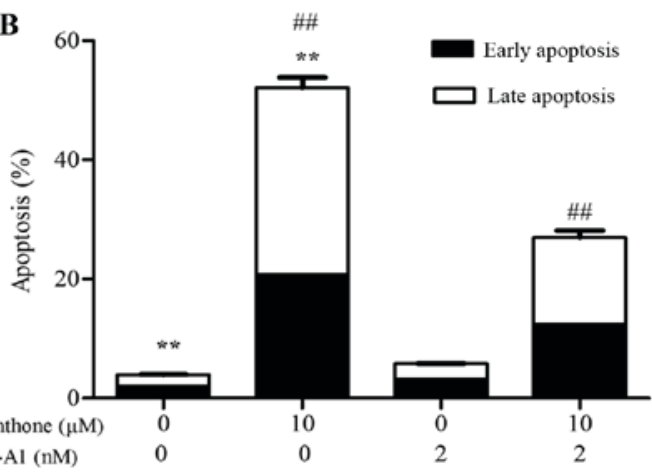

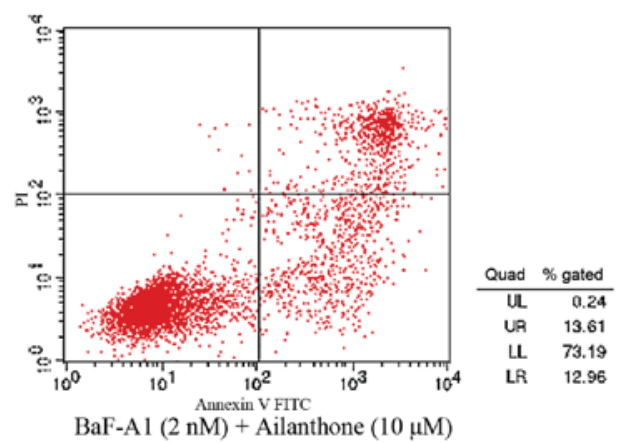

Figure 6. Autophagy is associated with ailanthone-mediated apoptosis of HL-60 cells. (A) Cells were pretreated with and without BaF-A1 (1 or 2 nM) for $30 \mathrm{~min}$, following treatment with and without ailanthone $(10 \mu \mathrm{M})$ for $48 \mathrm{~h}$ at $37^{\circ} \mathrm{C}$. MTT assay was used to determine the cell viability. (B) Cells were pretreated with and without BaF-A1 ( $2 \mathrm{nM})$ for $30 \mathrm{~min}$, following by treatment with and without ailanthone $(10 \mu \mathrm{M})$ for $48 \mathrm{~h}$ at $37^{\circ} \mathrm{C}$, $(\mathrm{C})$ annexin $\mathrm{V}-\mathrm{FITC}$ staining assay was used to analyze the cell apoptosis, ANOVA using Newman-Keuls multiple comparison test. ${ }^{*} \mathrm{P}<0.05$ vs. control, ${ }^{\#} \mathrm{P}<0.05$ vs. $(0,10 \mu \mathrm{M})$ groups, ${ }^{* *} \mathrm{P}<0.05$ vs. control, ${ }^{\# \#} \mathrm{P}<0.05$ vs. $(0,10 \mu \mathrm{M})$ groups. MTT, 3-(4,5-dimethylthiazol-2-yl)-2,5-diphenyl-tetrazoliumbromide.

in the autophagy process, during which cytoplasmic pattern LC3 (LC3-I) is converted to autophagosomal membrane LC3 (LC3-II), resulting in elevated LC3-II levels (35). The beclin-1 gene is located on chromosome $17 \mathrm{q} 21$, which is homologous with the yeast autophagy gene Apg6/Vps30 and involves in the composition of the class III PI3K complex (36). Beclin-1 is a critical protein in the formation of autophagosome encoded by beclin-1 gene. Beclin-1 may mediate cell apoptosis by binding to the apoptosis-associated protein bcl-2 (37). p62 is a multifunctional ubiquitin protein, participating in the ubiquitin-proteasome system and the autophage system. With the occurrence of autophagy, p62 protein is incorporated into 
autophagosomes and then degraded (38). We found that ailanthone increased beclin-1 and LC3-II levels but decreased and p62 levels in a dose-dependent manner. Those results indicated that beclin-1, p62, and LC3 may participate in ailanthone inducted-autophagy in HL-60 cells. A recent paper found that ailanthone inhibits the proliferation activity of vestibular schwannoma cells by blocking the Ras/Ras/Raf/MEK/ERK and mTOR pathways through down-regulating the expression of mir-21. They observed that ailanthone reduced CyclinD1 protein levels, indicating that ailanthone may block vestibular schwannom cells in the G1 phase of cell cycle. Furthermore, their experiment also found that ailanthone enhanced the protein expression of LC3-II and Beclin-1, reduced the expression of p62, indicating that ailanthone may induce vestibular schwannom cells autophagy (39). Unlike this, our study is the first to demonstrate the potent-cytotoxicity of ailanthone against HL-60 cells. We observed the formation of acidic vesicular organelles by AO staining, visually see the characteristic performance of autophagy. In addition, we investigated whether ailanthone-induced autophagy is associated with apoptotic cell death in HL-60 cells. The MTT assay and annexin V-FITC staining assay suggested that the anti-proliferative and pro-apoptotic effects of ailanthone on HL-60 cells were significantly reversed following pretreatment of autophagy inhibitor BaF-A1. These results suggested that ailanthone-induced autophagy may play a pivotal role in apoptotic cell death in human promyelocytic leukemia cells.

In summary, the present study is the first to demonstrate that ailanthone extracted from Ailanthus altissima has anti-proliferative effects on HL-60 cells in vitro. We further found that these effects were partially due to the induction of apoptosis and G0/G1 phase cell cycle arrest. We found that ailanthone induces HL-60 cell autophagy possibly through the modulation of beclin-1, p62, and LC3 proteins expression. In addition, we found that the anti-proliferative and pro-apoptotic effects of ailanthone on HL-60 cells were significantly reversed by inhibiting autophagy. These results suggest that ailanthone-induced autophagy in the HL-60 cells likely involves autophagic cell death. However, considering the potential fluctuation of p62 and LC3-II levels during the process, the absence of data at other time points besides $48 \mathrm{~h}$ would be a limitation of the present study. Further studies are need to determine the details of the mechanism underlying autophagic and apoptotic cell death induced by ailanthone in leukemia cells, and to evaluate the anti-proliferative effects of ailanthone on leukemia cells in vivo. Our results revealed the pharmacological activity of ailanthone on HL-60 cells and suggest that ailanthone could be a suitable therapeutic agent for the treatment of leukemia.

\section{Acknowledgements}

The authors would like to thank the Institute of Traditional Chinese Medicine and Natural Products, Jinan University for providing the pure sample of ailanthone.

\section{Funding}

The present study was supported by the National Natural Science Foundation of China (grant no. 81241102).

\section{Availability of data and materials}

The datasets used and analyzed during the current study are available from the corresponding author on reasonable request.

\section{Authors' contributions}

$\mathrm{ZJ}$ and $\mathrm{CW}$ designed the study. $\mathrm{CW}$ was a major contributor in writing the manuscript. CC and YC performed cell culture and MTT assay experiments. LZ and YW performed the experiments and analyzed the data regarding ailanthone-induced apoptosis and cell cycle arrest in HL-60 cells. CL performed AO staining. YH and ZY performed western blotting. All authors read and approved the final manuscript.

\section{Ethics approval and consent to participate}

Not applicable.

\section{Patient consent for publication}

Not applicable.

\section{Competing interests}

The authors declare that they have no competing interests.

\section{References}

1. Vardiman JW, Thiele J, Arber DA, Brunning RD, Borowitz MJ, Porwit A, Harris NL, Le Beau MM, Hellström-Lindberg E, Tefferi A and Bloomfield CD: The 2008 revision of the World Health Organization (WHO) classification of myeloid neoplasms and acute leukemia: Rationale and important changes. Blood 114: 937-951, 2009.

2. Routledge DJ and Bloor AJ: Recent advances in therapy of chronic lymphocytic leukaemia. Br J Haematol 174: 351-367, 2016.

3. Wang Y, Wang WJ, Su C, Zhang DM, Xu LP, He RR, Wang L, Zhang J, Zhang XQ and Ye WC: Cytotoxic quassinoids from Ailanthus altissima. Bioorg Med Chem Lett 23: 654-657, 2013.

4. kundu P and Laskar S: A brief resume on the genus Ailanthus: Chemical and pharmacological aspects. Phytochem Rev 9: pp379-412, 2010.

5. Okunade AL, Bikoff RE, Casper SJ, Oksman A, Goldberg DE and Lewis WH: Antiplasmodial activity of extracts and quassinoids isolated from seedlings of Ailanthus altissima (Simaroubaceae). Phytother Res 17: 675-677, 2003.

6. Fukamiya N, Lee KH, Muhammad I, Murakami C, Okano M, Harvey I and Pelletier J: Structure-activity relationships of quassinoids for eukaryotic protein synthesis. Cancer Lett 220: 37-48, 2005.

7. Rosati A, Quaranta E, Ammirante M, Turco MC, Leone A and De Feo V: Quassinoids can induce mitochondrial membrane depolarisation and caspase 3 activation in human cells. Cell Death Differ 11 (Suppl 2): S216-S218, 2004.

8. Yang XL, Yuan YL, Zhang DM, Li F and Ye WC: Shinjulactone $\mathrm{O}$, a new quassinoid from the root bark of Ailanthus altissima. Nat Prod Res 28: 1432-1437, 2014.

9. Zhuo Z, Hu J, Yang X, Chen M, Lei X, Deng L, Yao N, Peng Q, Chen Z, Ye W and Zhang D: Ailanthone inhibits Huh7 cancer cell growth via cell cycle arrest and apoptosis in vitro and in vivo. Sci Rep 5: 16185, 2015.

10. Evan GI and Vousden KH: Proliferation, cell cycle and apoptosis in cancer. Nature 411: 342-348, 2001.

11. Kondo S, Tanaka Y, Kondo Y, Hitomi M, Barnett GH, Ishizaka Y, Liu J, Haqqi T, Nishiyama A, Villeponteau B, et al: Antisense telomerase treatment: Induction of two distinct pathways, apoptosis and differentiation. FASEB J 12: 801-811, 1998.

12. Portt L, Norman G, Clapp C, Greenwood M and Greenwood MT: Anti-apoptosis and cell survival: A review. Biochim Biophys Acta 1813: 238-259, 2011. 
13. Klionsky DJ, Abdelmohsen K, Abe A, Abedin MJ, Abeliovich $\mathrm{H}$, Acevedo Arozena A, Adachi H, Adams CM, Adams PD, Adeli K, et al: Guidelines for the use and interpretation of assays for monitoring autophagy (3rd edition). Autophagy 12: 1-222, 2016.

14. Paglin S, Hollister T, Delohery T, Hackett N, McMahill M, Sphicas E, Domingo D and Yahalom J: A novel response of cancer cells to radiation involves autophagy and formation of acidic vesicles. Cancer Res 61: 439-444, 2001.

15. Kondo Y, Kanzawa T, Sawaya R and Kondo S: The role of autophagy in cancer development and response to therapy. Nat Rev Cancer 5: 726-734, 2005.

16. Klionsky DJ and Emr SD: Autophagy as a regulated pathway of cellular degradation. Science 290: 1717-1721, 2000.

17. Kanzawa T, Kondo Y, Ito H, Kondo S and Germano I: Induction of autophagic cell death in malignant glioma cells by arsenic trioxide. Cancer Res 63: 2103-2108, 2003.

18. Tsang CK, Qi H, Liu LF and Zheng XF: Targeting mammalian target of rapamycin (mTOR) for health and diseases. Drug Discov Today 12: 112-124, 2007

19. Xia Z, Zhang H, Xu D, Lao Y, Fu W, Tan H, Cao P, Yang L and $\mathrm{Xu} \mathrm{H}$ : Xanthones from the leaves of garcinia cowa induce cell cycle arrest, apoptosis, and autophagy in cancer cells. Molecules 20: 11387-11399, 2015.

20. Schwartz GK and Shah MA: Targeting the cell cycle: A new approach to cancer therapy. J Clin Oncol 23: 9408-9421, 2005.

21. Pardee AB: A restriction point for control of normal animal cel proliferation. Proc Natl Acad Sci USA 71: 1286-1290, 1974.

22. Sherr CJ: The Pezcoller lecture: Cancer cell cycles revisited. Cancer Res 60: 3689-3695, 2000.

23. Watson NC, Di YM, Orr MS, Fornari FA Jr, Randolph JK, Magnet KJ, Jain PT and Gewirtz DA: Influence of ionizing radiation on proliferation, c-myc expression and the induction of apoptotic cell death in two breast tumour cell lines differing in p53 status. Int J Radiat Biol 72: 547-559, 1997.

24. Lavhale MS, Kumar S, Mishra SH and Sitasawad SL: A novel triterpenoid isolated from the root bark of Ailanthus excelsa Roxb (Tree of Heaven), AECHL-1 as a potential anti-cancer agent. PLoS One 4: e5365, 2009.

25. Wang ZH, Peng ZL, Duan ZL and Liu H: Expression and clinical significance of autophagy gene Beclin 1 in cervical squamous cell carcinoma. Sichuan Da Xue Xue Bao Yi Xue Ban 37 860-863, 2006 (In Chinese).

26. Xu MY, Lee DH, Joo EJ, Son KH and Kim YS: Akebia saponin PA induces autophagic and apoptotic cell death in AGS human gastric cancer cells. Food Chem Toxicol 59: 703-708, 2013.
27. Mizushima N, Ohsumi Y and Yoshimori T: Autophagosome formation in mammalian cells. Cell Struct Funct 27: 421-429, 2002.

28. Česen MH, Pegan K, Spes A and Turk B: Lysosomal pathways to cell death and their therapeutic applications. Exp Cell Res 318: 1245-1251, 2012

29. Yamamoto A, Tagawa Y, Yoshimori T, Moriyama Y, Masaki R and Tashiro Y: Bafilomycin A1 prevents maturation of autophagic vacuoles by inhibiting fusion between autophagosomes and lysosomes in rat hepatoma cell line, H-4-II-E cells. Cell Struct Funct 23: 33-42, 1998.

30. Klionsky DJ, Elazar Z, Seglen PO and Rubinsztein DC: Does bafilomycin A1 block the fusion of autophagosomes with lysosomes? Autophagy 4: 849-850, 2008.

31. Mehdi S: Cell-penetrating inhibitors of calpain. Trends Biochem Sci 16: 150-153, 1991.

32. Seglen PO, Grinde B and Solheim AE: Inhibition of the lysosomal pathway of protein degradation in isolated rat hepatocytes by ammonia, methylamine, chloroquine and leupeptin. Eur J Biochem 95: 215-225, 1979.

33. Phadwal K, Watson AS and Simon AK: Tightrope act: Autophagy in stem cell renewal, differentiation, proliferation, and aging. Cell Mol Life Sci 70: 89-103, 2013.

34. Gozuacik D and Kimchi A: Autophagy as a cell death and tumor suppressor mechanism. Oncogene 23: 2891-2906, 2004.

35. Tanida I, Ueno T and Kominami E: LC3 conjugation system in mammalian autophagy. Int J Biochem Cell Biol 36: 2503-2518, 2004.

36. Seaman MN, Marcusson EG, Cereghino JL and Emr SD: Endosome to Golgi retrieval of the vacuolar protein sorting receptor, Vps10p, requires the function of the VPS29, VPS30, and VPS35 gene products. J Cell Biol 137: 79-92, 1997.

37. Pattingre S, Tassa A, Qu X, Garuti R, Liang XH, Mizushima N, Packer M, Schneider MD and Levine B: Bcl-2 antiapoptotic proteins inhibit Beclin 1-dependent autophagy. Cell 122: 927-939, 2005.

38. Mizushima N and Komatsu M: Autophagy: Renovation of cells and tissues. Cell 147: 728-741, 2011.

39. Yang P, Sun D and Jiang F: Ailanthone promotes human vestibular schwannoma cells apoptosis and autophagy by down-regulation of miR-21. Oncol Res: Jan 3, 2018 (Epub ahead of print).

(i) () This work is licensed under a Creative Commons Attribution-NonCommercial-NoDerivatives 4.0 International (CC BY-NC-ND 4.0) License. 